MICHEL-JONES (Françoise), Retour aux Dogon. Figures du double et ambivalence

Paris, L'Harmattan, 1999 (1978), 157 p., (bibliogr.) (coll. « Connaissance des hommes »)

Yves Lambert

\title{
CpenEdition
} Journals

Édition électronique

URL : http://journals.openedition.org/assr/20921

DOI : $10.4000 /$ assr.20921

ISSN : 1777-5825

Éditeur

Éditions de l'EHESS

Édition imprimée

Date de publication : 1 juin 2001

Pagination : 148

ISBN : 2-222-96704-X

ISSN : 0335-5985

Référence électronique

Yves Lambert, "MICHEL-JONES (Françoise), Retour aux Dogon. Figures du double et ambivalence », Archives de sciences sociales des religions [En ligne], 114 | avril-juin 2001, document 114.94, mis en ligne le 19 août 2009, consulté le 21 septembre 2020. URL : http://journals.openedition.org/assr/ 20921 ; DOI : https://doi.org/10.4000/assr.20921

Ce document a été généré automatiquement le 21 septembre 2020.

(C) Archives de sciences sociales des religions 


\section{MICHEL-JONES (Françoise), Retour aux Dogon. Figures du double et ambivalence}

Paris, L'Harmattan, 1999 (1978), 157 p., (bibliogr.) (coll. « Connaissance des hommes »)

Yves Lambert

\section{RÉFÉRENCE}

MICHEL-JONES (Françoise), Retour aux Dogon. Figures du double et ambivalence, Paris, L'Harmattan, 1999 (1978), 157 p., (bibliogr.) (coll. «Connaissance des hommes »)

C'est la réédition, avec une nouvelle préface, d'un ouvrage paru en 1978. Le point de départ est le constat selon lequel Marcel Griaule et Germaine Dieterlen, dans leur souci d'élever les Dogon à une haute dignité et dans leur priorité accordée au symbolique, ont eu tendance à donner de la société dogon une image d'harmonie et de fonctionnalité qui ne correspond pas à la réalité. Ainsi les faits de sorcellerie, de conflit, de divorce ne retiennent guère l'attention; l'interprétation des représentations, fondamentales, de la gémellité mixte, de l'ambivalence sexuelle et de la dualité mettant l'accent sur les aspects de complémentarité organique au détriment de ceux de contradiction et d'inégalité. L'auteur souligne que la réalité est faite d'une forte domination masculine et de tensions parfois aiguës, que, d'ailleurs, ces représentations voilent à peine. Le simple fait que l'excision soit donnée à voir comme le simple équivalent de la circoncision est une illustration typique de ce déséquilibre des deux termes et de sa fonction idéologique. Ce travail permet de rétablir une vision plus réaliste des choses même s'il a parfois tendance à tordre le bâton dans l'autre sens. 